\section{Effect of Drying-Wetting Process on Friction CAPACITY AND AdHESION FACTOR OF PILE FOUNDATION IN CLAYEY SOIL}

\author{
Daniel Tjandra*, Indarto, Ria Asih Aryani Soemitro
}

Civil Engineering Department, Sepuluh Nopember Institute of Technology (ITS), Surabaya, Indonesia, Campus ITS Sukolilo, Surabaya, East Java, Indonesia, 60111
Article history

Received

3 August 2015

Received in revised form

31 August 2015

Accepted

23 September 2015

*Corresponding author danieltj@petra.ac.id

\section{Graphical abstract}

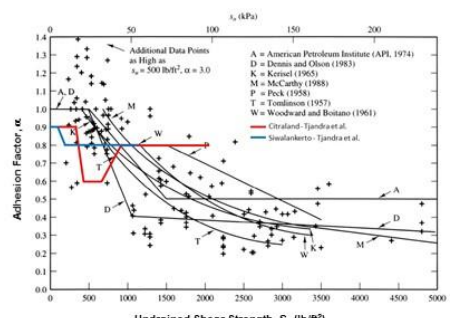

\begin{abstract}
Clayey soils had a seasonal water content change, which occurred in the zone known as active zone. This change happen due to the seasonal drying and wetting cycles, which affects the fluctuation of water table. The water content variation causes the change in undrained shear strength and these changes have an impact to the friction capacity and adhesion factor of pile foundation. This paper discusses the undrained shear strength, friction capacity of pile and adhesion factor of piles under drying and wetting cycles. Research was conducted on two different types of clayey soils. Laboratory experiments for varying soil water content were done. Soil samples were placed in a cylinder tube, the concrete pile model was then inserted into the soil. The diameter of the tube was about 15 times of the pile diameter. Loading test was carried out to investigate pile friction capacity. The result of this study showed that there was great effect of seasonal water content change on undrained shear strength, friction capacity and also adhesion factor of pile in the clayey soils.
\end{abstract}

Keywords: Undrained shear strength, friction capacity, adhesion factor

\begin{abstract}
Abstrak
Tanah liat mempunyai perubahan kandungan air bermusim, yang berlaku dalam zon yang dikenali sebagai zon aktif. Perubahan ini berlaku disebabkan oleh kitaran pengeringan dan pembasahan bermusim, yang memberi kesan kepada perubahan paras air. Perubahan kandungan air diikuti dengan perubahan kekuatan ricih tak tersalir dan perubahan ini memberi kesan kepada keupayaan geseran dan faktor rekatan cerucuk. Kertas kerja ini membincangkan berkenaan kekuatan ricih tak tersalir, keupayaan geseran cerucuk dan faktor rekatan cerucuk di bawah kitaran pengeringan dan pembasahan. Kajian telah dijalankan ke atas dua jenis tanah liat. Ujikaji makmal bagi kandungan air tanah yang berbeza telah dilakukan. Sampel tanah telah diletakkan di dalam tiub silinder, model cerucuk konkrit kemudian dimasukkan ke dalam tanah. Diameter tiub adalah kira-kira 15 kali ganda diameter cerucuk. Ujikaji pembebanan telah dijalankan untuk menyiasat geseran kapasiti cerucuk. Hasil ujikaji menunjukkan terdapat kesan yang besar dari perubahan kandungan air bermusim terhadap kekuatan ricih tak tersalir, keupayaan geseran dan juga faktor rekatan cerucuk dalam tanah liat.
\end{abstract}

Kata kunci: Kekuatan ricih tak tersalir, keupayaan geseran, faktor rekatan

(C) 2015 Penerbit UTM Press. All rights reserved 


\subsection{INTRODUCTION}

Indonesia has two seasons, as dry and wet seasons which cause variations in soil moisture content. This two distinct seasons cause the groundwater table fluctuations on soil with shallow depth of the water table. While on the soil which have groundwater table far away from the surface, the change of seasons resulted in a variation of the moisture content until a certain depth from the surface. An area where the water content in the soil is always changing due to the influence of the change of seasons is called the active zone. The active zone is defined as the depth in a soil to which periodic changes of moisture content [1].

Variation of water content in the active zone leads to changes in the physical and mechanical characteristics of the soil. Especially, when soil changes from saturated to unsaturated condition, which was shown by air entry value [2-3]. Beside of that, changes in water content can also cause shrinkage and changes in the volume of soil [4-9]. Therefore, it should be considered for foundation built on this active zone.

It is noteworthy that drying-wetting process. This process change shear strength parameters of soil, which used in the calculation of pile friction capacity. Figure 1 shows the correlation between undrained shear strength $(\mathrm{Su})$ and adhesion factor (a) proposed by several previous studies [10].

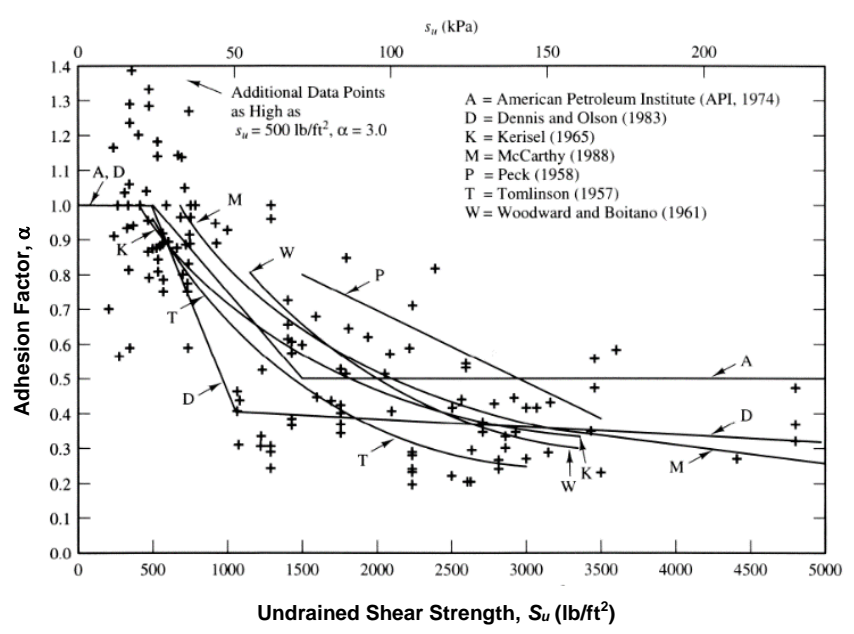

Figure 1 Correlation between adhesion factor and undrained shear strength [10]

The graphs of adhesion factor is also not known whether can be applied to the bearing capacity of friction piles for all types of soil. This research was conducted on two different types of clayey soils. Laboratory experiments for varying soil water content were done. The purpose of this study was to investigate undrained shear strength, friction capacity and adhesion factor of piles under drying and wetting cycles.

\subsection{EXPERIMENTAL PROCEDURES}

In this study, field and laboratory investigation were done on soil sample taken from Citraland, West Surabaya, Indonesia and Siwalankerto, South Surabaya, Indonesia. Citraland clay is expansive clay and in this research was represented as a soil under negative pore pressure. In real field condition, Citraland clay might be as unsaturated, pseudo saturated or saturated soil. While, Siwalankerto clay was represented as soft clay under positive pore pressure. The changing of water content in Citraland was caused by water infiltration and evaporation. On Siwalankerto, the changing was caused by the fluctuation of ground water table. The initial characteristics of soil sample can be seen in Table 1.

Table 1 Initial characteristic of soil sample

\begin{tabular}{|c|c|c|}
\hline Initial Characteristics & Citraland & Siwalankerto \\
\hline Water Content (\%) & 44.5 & 58.1 \\
\hline Specific Gravity & 2.65 & 2.51 \\
\hline Unit Weight, $Y_{+}\left(\mathrm{gr} / \mathrm{cm}^{3}\right)$ & 1.81 & 1.64 \\
\hline $\begin{array}{l}\text { Dry Unit Weight, Yd } \\
\left(\mathrm{gr} / \mathrm{cm}^{3}\right)\end{array}$ & 1.25 & 1.04 \\
\hline Void Ratio, e & 1.11 & 1.38 \\
\hline Liquid Limit (\%) & 109 & 67.5 \\
\hline Plastic Limit (\%) & 30 & 25 \\
\hline Shrinkage Limit (\%)* & 26 & 18 \\
\hline Plasticity Index (\%) & 79 & 42.5 \\
\hline \% Gravel & 0 & 0 \\
\hline \% Sand & 0.11 & 15.5 \\
\hline \% Silt & 23 & 34.2 \\
\hline$\%$ Clay & 76.8 & 50.3 \\
\hline $\begin{array}{l}\text { Undrained Shear Strength, } \\
\mathrm{Cu}_{u}\left(\mathrm{~kg} / \mathrm{cm}^{2}\right)\end{array}$ & 0.26 & 0.036 \\
\hline Soil Classification (USCS) & $\mathrm{CH}$ & $\mathrm{CH}$ \\
\hline
\end{tabular}

Citraland clay has a water content value lower than Siwalankerto clay, because the soil at Siwalankerto has a high ground water level and soil samples was taken below groundwater level. The existence of ground water level causes Siwalankerto clay has a lower dry unit weight. This is indicated by the soil unit weight which was lower than Citraland clay and void ratio which was higher than Citraland clay.

Based on Unified Soil Classification System (USCS), Citraland and Siwalankerto soil were classified as clay soil with high plasticity $(\mathrm{CH})$. Citraland clay had a higher level of plasticity than Siwalankerto clay. This is indicated by the value of plasticity index of Citraland clay which was much higher than the Siwalankerto clay. The high plasticity index of Citraland soil was caused by the percentage of clay particles in the soil which was higher than the Siwalankerto soil. The hydrometer test results showed that the percentage of clay in the Citraland soil was $76.8 \%$ and $50.3 \%$ for Siwalankerto soil.

Pile friction capacities under drying and wetting cycles were determined by field and laboratory tests. Details of the field and laboratory tests can be seen in previous studies [11-12]. Field research at the location of soil sampling was done to determine the 
accuracy level of the results of this research in the laboratory. The results showed as $80 \%$ of accuracy [11]. Thus, drying and wetting process conducted in the laboratory could be represented the field condition during the changing seasons.

The undisturbed soil samples were taken at a depth of approximately 1 meter. Soil sampling was done using a PVC tube with $15.24 \mathrm{~cm}$ diameter and $15 \mathrm{~cm}$ long. The determination of tube diameter was considering the boundary effect of 15 times pile diameter [13-14].In the laboratory experiment, concrete piles with $1 \mathrm{~cm}$ in diameter and $30 \mathrm{~cm}$ in length were used. It can be seen in Figure 2 that a pile model was inserted into the soil sample in order to obtain its friction capacity.

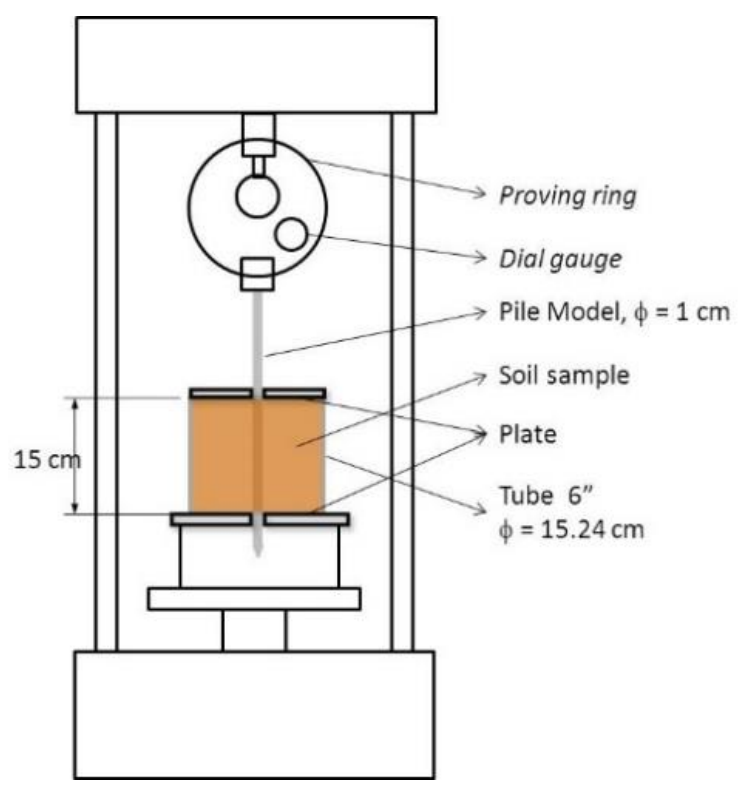

Figure 2 Laboratory model pile

The soil sample in the PVC tube was tested with various water contents. The variation of water content was based on the secondary data of soil moisture content variation in field due to seasonal change. Wetting condition was obtained by adding water into the soil which was placed in the PVC tube with a certain weight in each condition. As for the drying, the soil inside the PVC tube was drained until the predetermined weight. Wetting and drying process is shown in Figure 3 and Figure 4. The variation of water contents and degree of saturation in this research are shown in Table.In expansive clay (Citraland), the soil might still be in saturated condition even though there was a decrease in water content under drying process. It was caused by the high volume change behavior in expansive clay.

By varying the water content, undrained shear strength tests were conducted in this study. Determination of undrained shear strength was done by unconfined compression test for drying condition and vane test for wetting condition. Based on undrained shear strength and pile friction capacity from test results, adhesion factor was determined by dividing pile friction capacity by undrained shear strength and contact area between pile and soil [11].

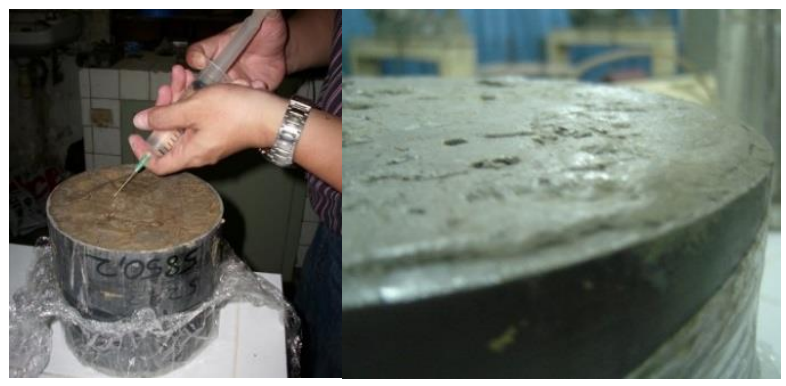

Figure 3 Wetting process

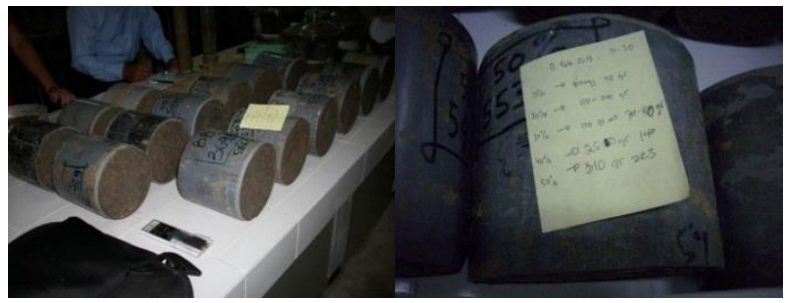

Figure 4 Drying process

Table 2 Drying and wetting condition

\begin{tabular}{ccc}
\hline Drying- & \multicolumn{2}{c}{ Water Content (\%) } \\
\cline { 2 - 3 } $\begin{array}{c}\text { Wetting } \\
\text { Condition }\end{array}$ & Citraland & Siwalankerto \\
\hline Wetting 15\% & $51.18\left(\mathrm{~S}_{\mathrm{r}}=100 \%\right)$ & - \\
Wetting 10\% & $48.95\left(\mathrm{~S}_{\mathrm{r}}=100 \%\right)$ & - \\
Wetting 5\% & $46.73\left(\mathrm{~S}_{\mathrm{r}}=100 \%\right)$ & - \\
Initial & $44.50\left(\mathrm{~S}_{\mathrm{r}}=100 \%\right)$ & 58.11 \\
Drying $10 \%$ & $40.05\left(\mathrm{~S}_{\mathrm{r}}=100 \%\right)$ & $52.30\left(\mathrm{~S}_{\mathrm{r}}=93 \%\right)$ \\
Drying $20 \%$ & $35.60\left(\mathrm{~S}_{\mathrm{r}}=94 \%\right)$ & $46.49\left(\mathrm{~S}_{\mathrm{r}}=86 \%\right)$ \\
Drying 30\% & $31.15\left(\mathrm{~S}_{\mathrm{r}}=85 \%\right)$ & $40.68\left(\mathrm{~S}_{\mathrm{r}}=79 \%\right)$ \\
Drying $40 \%$ & $26.70\left(\mathrm{~S}_{\mathrm{r}}=75 \%\right)$ & $34.87\left(\mathrm{~S}_{\mathrm{r}}=70 \%\right)$ \\
Drying $50 \%$ & $22.25\left(\mathrm{~S}_{\mathrm{r}}=66 \%\right)$ & $29.06\left(\mathrm{~S}_{\mathrm{r}}=60 \%\right)$ \\
\hline
\end{tabular}

Note: Drying $x \% \rightarrow w_{c}(x)=w_{c \text { (initial) }}-x \% w_{c \text { (initial) }}$

Wetting $y \% \rightarrow w_{c(y)}=w_{c \text { (initial) }}+y \% w_{c \text { (initial) }}$

\subsection{RESULTS AND DISCUSSION}

\subsection{Undrained Shear Strength}

Changes in the water content and degree of saturation in Citraland clay have a significant effect on the strength of the soil. When soil conditions changed from liquid to plastic state and continued to solid state, the soil shear strength increased. As shown in Figure 5, the undrained shear strength decreased under wetting process. The undrained shear strength decreased due to an increase in pore water pressure and effective stress reduction in soil. On the contrary, undrained shear strength increased under drying process. Changes in the value of undrained shear strength, from drying $50 \%$ conditions $\left(w_{c}=22 \%\right.$ ) to wetting $15 \%$ conditions ( $W_{c}$ $=51 \%)$, reached 8.2 times. 
The range of water content variation, when it is placed on a global clay material, shows that the clay soil is in a plastic condition transforming to solid condition (Figure 5). When the soil condition was changed to solid state, the value of undrained shear strength significantly increased.

Changes in the water content and degree of saturation in Siwalankerto clay also cause significant effects on soil shear strength (Figure 6). Changes in the value of undrained shear strength, from initial condition $\left(w_{c}=58 \%\right.$ ) to drying $50 \%$ condition $\left(w_{c}=\right.$ $29 \%$ ), reached 15.4 times. The change of undrained shear strength in Siwalankerto clay was much greater than the changes in undrained shear strength in Citraland clay which was only about 8.2times.

This phenomenon could be explained by comparing the value of plasticity index (PI). Citraland clay has plasticity index value two times larger than Siwalankerto clay. Changes in undrained shear strength of Siwalankerto clay were two times larger than the clay in Citraland with the same variations in water content. Thus, change of undrained shear strength value was also influenced by soil plasticity index.

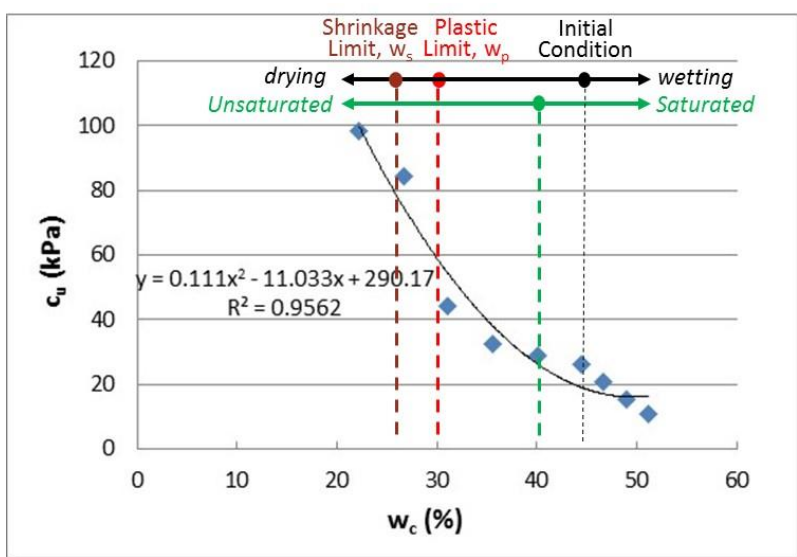

Figure 5 Undrained shear strength under drying-wetting process of Citraland clay

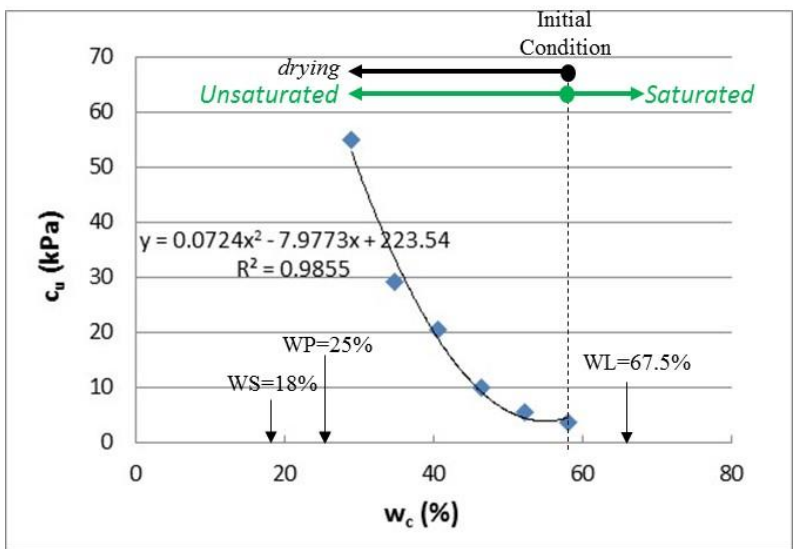

Figure 6 Undrained shear strength under drying-wetting process of Siwalankerto clay
Degree of saturation in both clay soils had great effect on the change of undrained shear strength value. When soil condition was changed from saturated to unsaturated, undrained shear strength significantly increased, as shown in Figure 5 and Figure 6. As the phase of soil was changed into unsaturated condition, negative pore water pressure increased effectively. Negative pore water pressure potentially increased the effective stress of the soil.

\subsection{Friction Capacity}

Pile friction capacity was determined by dividing the friction load by the surface area of pile model. Friction capacity of pile at Citraland soil decreased with increasing water content as shown in the relationship between water content and pile friction capacity in Figure 7. The difference of pile friction capacity in the range of water content between $22 \%$ (drying $50 \%$ ) to $51 \%$ (wetting $15 \%$ ) reached 8.7 times.

Drying and wetting process also causes significant impact on the pile friction capacity at Siwalankerto soil. The difference of pile friction capacity in the range water content between $58 \%$ (initial condition) to $29 \%$ (drying $50 \%$ ) reached 13.6 times. The relationship between the water content and friction capacity of pile on Siwalankerto clay can be seen in Figure 8. With the same water content variation around $29 \%$, the difference of pile friction capacity in Siwalankerto clay was greater than Citraland clay.

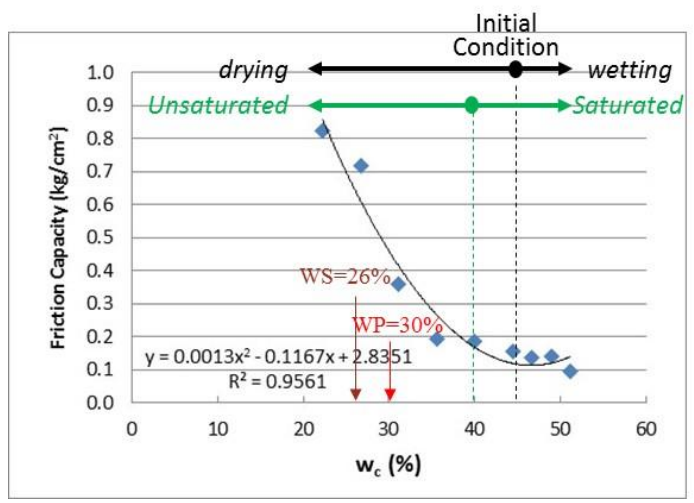

Figure 7 Pile friction capacity under drying-wetting process on Citraland clay

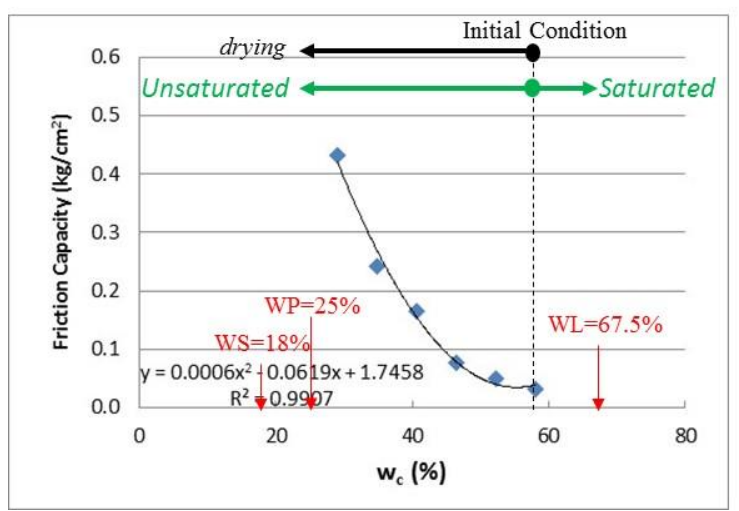

Figure 8 Pile friction capacity under drying-wetting process on Siwalankerto clay 
The changes in friction capacity can be associated to the PI of the soils. As in the case of undrained shear strength, soil with higher PI resulted in lower friction capacity than that of soil with lower PI. Similarly, the degree of saturation also has significant impact on friction capacity. As the degree of saturation decreased due to drying, the development of negative pore water pressure increased the effective stress thus the shear strength and friction capacity. Such changes can be observed in Figure 7 and Figure 8.

\subsection{Adhesion Factor}

In this research, the adhesion factor was obtained by dividing the pile friction capacity by undrained shear strength. The relationship between the undrained shear strength of Citraland and adhesion factor of pile can be seen in Figure 9. Under saturated condition, the value of adhesion factor is relatively constant value at 0.9 . This adhesion factor decreased significantly to 0.6 at the time of Air Entry Value (AEV) when soil state changes from saturated to unsaturated condition. The values of adhesion factor increased when the value of undrained shear strength exceeds $30 \mathrm{kPa}$. When the value of undrained shear strength reached $45 \mathrm{kPa}$, where the soil has been in solid state, the adhesion factor was constant in the value of 0.8 until soil water content reach shrinkage limit.

In general, an increase in undrained shear strength followed by a decrease in the value of adhesion factor. However, in the case of Citraland soil which was called expansive soil, it is necessary to know and understand the behavior of expansive soil itself. This type of clay was high plasticity clay, which had a high plasticity index. High plasticity clay affected to the density and cohesion of the soil. When the water content decreased, clay has been changed from plastic to semi solid state, the soil cohesion increased and the soil become stickier. The soil cohesion affects the adhesiveness of the soil against a pile material. Thus it is possible in these conditions that the value of adhesion factor has increased.

As shown in Figure 9, when the phase of soil was changed from saturated soil to unsaturated ( $\mathrm{CU}>30$ $\mathrm{kPa})$, pore water pressure became negative. Negative pore water pressure potentially increased the effective stress of soil so that adhesion between soil and pile material became stronger.

The relationship between the undrained shear strength and adhesion factor for saturated clay in Siwalankerto can be seen in Figure 10. The graph has the same trend as the graph of undrained shear strength and adhesion factors that have been proposed by some previous researchers (Figure 11). When undrained shear strength value was smaller than $5 \mathrm{kPa}$, which soil wasin saturated condition, the value of adhesion factor was 0.9. The adhesion factor then decreased to 0.8 when entering the phase of unsaturated soil with undrained shear strength value was $10 \mathrm{kPa}$. After that point, adhesion factor value was kept constant with the increasing of undrained shear strength.
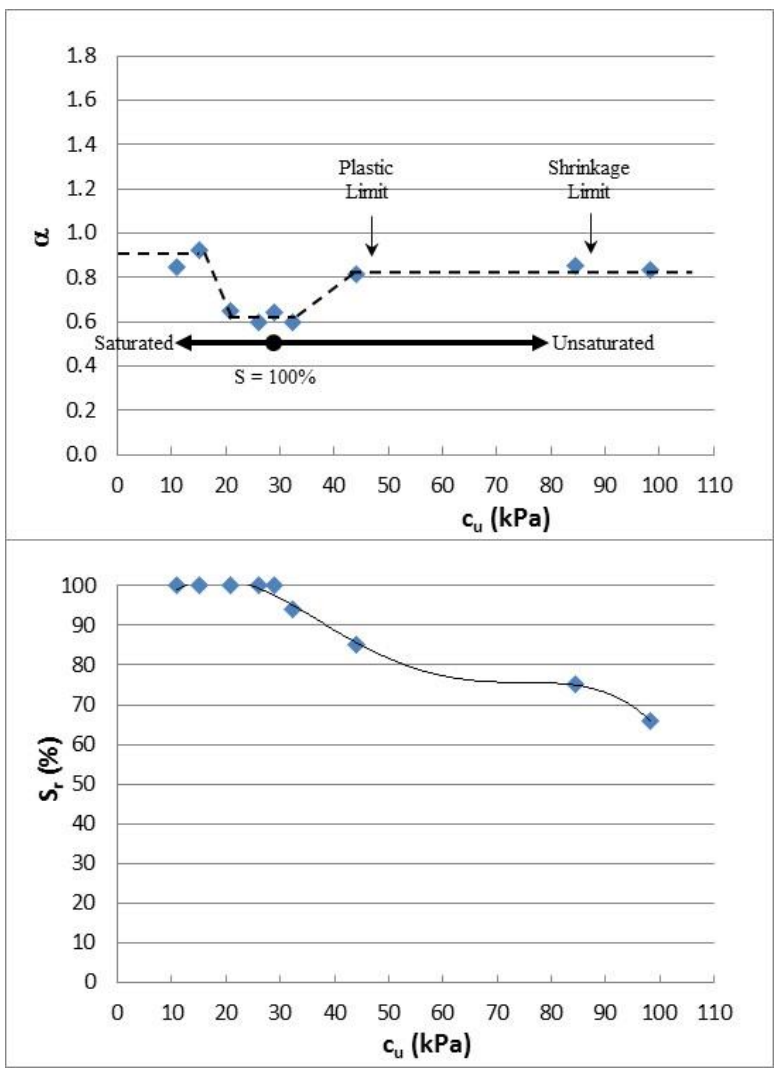

Figure 9 Correlation between adhesion factor and degree of saturation with undrained shear strength for Citraland Clay

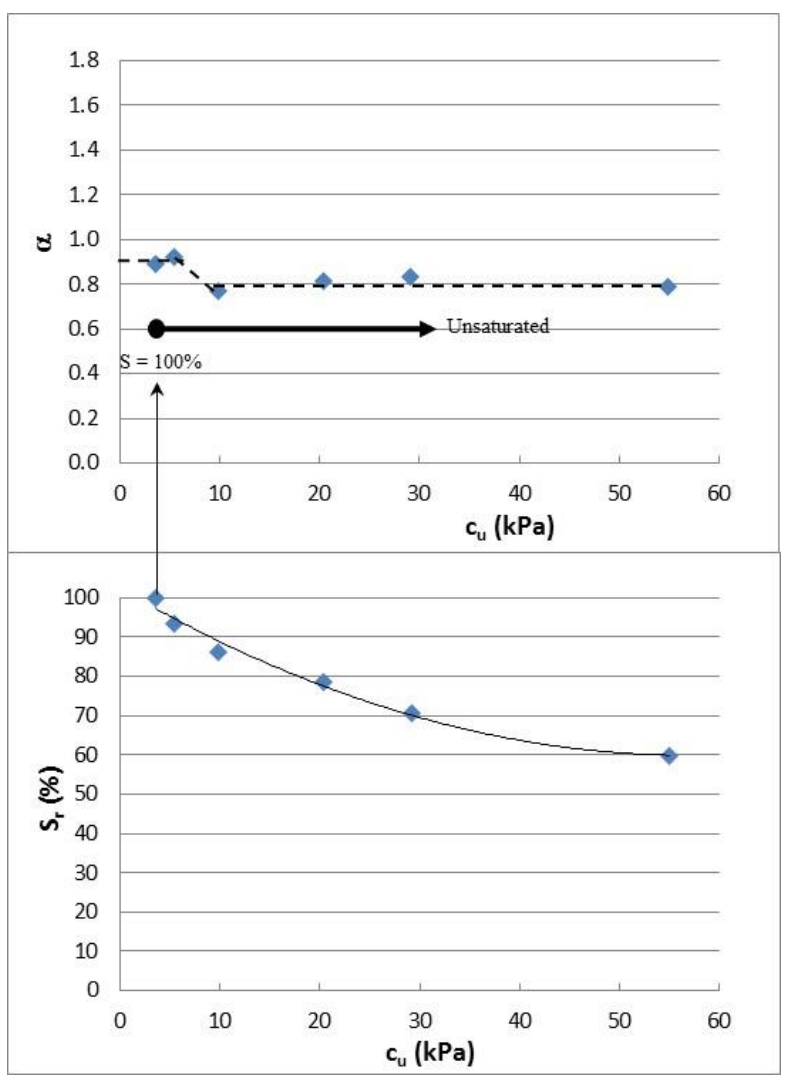

Figure 10 Correlation between adhesion factor and degree of saturation with undrained shear strength for Siwalankerto clay 
Differences between adhesion factor of Citraland and Siwalankerto clays to adhesion factors proposed by some previous researchers can be observed. The differences were due to the adhesion factors proposed by several researchers, were obtained empirically from pile loading test results in the field with real scale. While in this research, testing was done by using the pile model in the laboratory. Adhesion factor proposed by several researchers at Figure 11 can be clearly seen with spread dots of adhesion factor in different value with same undrained shear strength value.

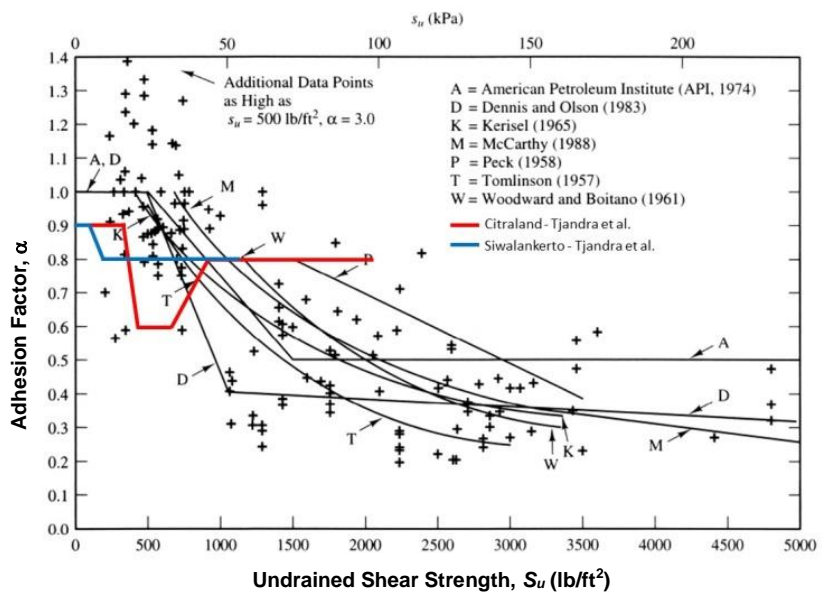

Figure 11 Comparison of Adhesion Factors with Some Researchers

\subsection{CONCLUSION}

Field and laboratory tests were performed to investigate the impact of water content variations on adhesion factor of pile friction capacity. From this study, it can be concluded as follows:

1. The variation of water content in drying and wetting process greatly affected soil shear strength. The undrained shear strength decreased up to 8.2 times for Citraland clay as water content increased from $22 \%$ to $51 \%$, while for Siwalankerto clay, the reduction was up to 15.4 times as water content increased from $29 \%$ to $58 \%$.

2. Drying and wetting process greatly affected the friction capacity of pile. In Citraland clay, the friction capacity of pile was reduced up to 8.7 times when water content increased from $22 \%$ to $51 \%$. As comparison, pile friction capacity in Siwalankerto soil decreased up to 13.6 times when water content increased from $29 \%$ to $58 \%$.

3. This study had approximately the same trend of correlation between undrained shear strength and adhesion factor proposed by some previous studies, especially for Siwalankerto clay. On the other side, since the undrained shear strength at Citraland clay was higher than $30 \mathrm{kPa}$, the adhesion factor increased with the increased of undrained shear strength. This was contrary to the previous findings. This was expected as greater undrained shear strength occurred due to the lowering of water content, causing the increased of adhesiveness between soil and pile.

\section{Acknowledgement}

This study is supported by the Department of Civil Engineering, Sepuluh Nopember Institute of Technology (ITS), Surabaya, Indonesia and the Department of Civil Engineering, Petra Christian University, Surabaya, Indonesia. The authors greatly acknowledge for all the support received.

\section{References}

[1] Das B.M. 1999. Principles of Geotechnical Engineering California: PWS Publishing.

[2] Ajdari, M., Habibagahi, G., Nowamooz, H., Masrouri, F. and Ghahramani. A. 2010. Shear Strength Behavior and Soil Water Retention Curve of a Dual Porosity SiltBentonite Mixture. Transaction A: Civil Engineering. 17(6) 430-440.

[3] Konyai, S., Sriboonlue, V. and Trelo-Ges, V. 2009. The Effect of Air Entry Value on hysterisis of Water Retention Curve in Saline Soil. American Journal of Environmental Sciences. 5(3): 341-345.

[4] Muntaha, M., Soemitro, R.A. and Noor Endah. 2010. Characteristics of Tropical Residual Soils in Arjasa Jember of East Java. International Journal of Academic Research. 2(5): 177-183.

[5] Indarto. 2008. Peranan Siklus Drying - Weeting terhadap Kegagalan Pondasi.Proceedings Seminar HATI. Bandung.

[6] Yalcin, A. 2011. A Geotechnical Study on the Landslides in the Trabzon Province. NE. Turkey. Applied Clay Science. 52: 11-19.

[7] Badawi, S. dan Indarto. 2010. Behaviour of Expansive Undisturbed Soil and Remoulded Soil under Drying and Wetting Cycle. Seminar Nasional VI 2010 Teknik Sipil ITS Surabaya. 105-112.

[8] Au, S. W. C. 1998.Rain-Induced Slope Stability in Hong Kong, Engineering Geology. 51: 1-36.

[9] Shayea, N. A. 2001.The Combined Effect of Clay and Moisture Content on the Behavior of Remolded unsaturated Soils. Engineering Geology. 62: 319-342.

[10] Coduto, D. P. 2001. Foundation Design Principles and Practices. New Jersey: Prentice-Hall, Inc. (Printed and Electronically Reproduced By Permission Of Pearson Education, Inc., New York)

[11] Tjandra D., Indarto and Soemitro, R. A. A. 2013. The Effect of Water Content Variation on Adhesion Factor of Pile Foundation in Expansive Soil. Civil Engineering Dimension Journal. 13(2): 114-119.

[12] Tjandra, D., Indarto and Soemitro, R. A. A. 2014. The Influence of Water Content Variations on Friction Capacity of Piles in Expansive Soil. International Journal of ICT-aided Architecture and Civil Engineering. 1 (1): 31 40.

[13] Mhaidib, A.I. 2001. Effect of Rate of Loading on Uplift Capacity of a Model Pile in Clay.International Offshore and Polar Engineering Conference. Stavanger. Norway. 656-661.

[14] Poulos, H.G. 1994. Effect of Pile Driving on Adjacent piles in Clay. Canadian Geotechnical Journal. 31: 856-867. 